UDC 613.6.01

\title{
TO THE PROBLEM OF TYPOLOGY OF THE RISKOGENIC BEHAVIOUR (ANALYSIS ON THE EXAMPLE OF AN INDUSTRIAL ENTERPRISE OF PERM REGION)*
}

\author{
E.A. Ryazanova \\ FBSI "Federal Scientific Center for Medical and Preventive Health Risk Management Technologies", \\ 82 Monastyrskaya St., Perm, 614045, Russian Federation
}

This article offers a method for the typology of riskogenic behavior of employees. The method is based on the identification of the common patterns of behavior in terms of alcohol consumption, smoking, access to medical care, nutrition and physical activity. Three types of behavior, characterized by different levels of self-preservation, self-destructive activities and the degree of riskogenics, are given in this study. The first type is "low level of riskogenics, passive", that combines low levels of physical activity, high culture of consumption of alcoholic beverages, absence of smoking experience and correct eating habits. The second type - "average level of riskogenics, active" assumes daily exercises or sport activities, long walks in the fresh air, absence of dependence on alcohol beverages at severe nicotine dependence and absence of proper nutrition practices. A third type is "high level of riskogenic, passive" that involves systematic abuse of alcohol, heavy smoking, very poor nutrition and lack of exercise. The proposed typology was tested in an industrial plant producing rubber products for industrial and national consumption. The continuous sociological survey of employees of working specialties $(n=63)$ has been conducted. The parameterization of the behavioral practices of the respondents in the field of health (the indicators reflecting the average daily consumption of alcohol, nicotine uptake, integral index of food and motor activity were calculated) as well as the cluster analysis have been performed. The riskogenics first type comprises $30 \%$ of responded employees, the second $-52 \%$, the third - $18 \%$. For each type a social portrait has been composed. The analysis of relations between the type of riscogenic behavior of the employees and their health status indexes has been conducted.

Key words: riskogenic behavior, typology, risk assessment, employees of industrial enterprises, complex exposure

Introduction. Nowadays risk-generating behavior research is among the most outstanding and promising trends in risk-studying, risk sociology and health sociology [1,2,9-14 ]. When analyzing issues of risk assessment for working population scientists mostly concentrate on quantitative assessment of risk factors, danger levels related to industrial and economic activities of manufacturing enterprises, motor transport and health damage etc. [3; 6]. And here "riskgenerating behavior" category is to a great extent related to individual choice and personal behavioral patterns which are significant factors in diseases evolvement [2].

Our internal medical and sociological discourse dedicated to risk-generating behavior has two peculiarities. First, most contemporary scientific research deals with casual and motivational components of risk-generating behavior, their characteristics and peculiarities, as well as control and prevention techniques. And we really don't see enough research works aimed at developing risk-generating behavior typologies, population groups differentiation in terms of their risk-generating behavioral patterns, defining social profile peculiarities (as per social and demographic, social and economic characteristics etc.) for people who tend to follow risk-generating behavioral practices. And it makes it more complicated to work out and implement standard prevention programs aimed at prevention of diseases associated with hazardous factors.

Second, primary research target groups when we consider risk-generating behavior are teenagers $[1 ; 8]$. However, we can find a similarly important research object and it is working population, namely people employed at manufacturing enterprises and who represent the main development factor for our national economy and simultaneously the result of this development. The

(C) Ryazanova E.A., 2016

Ryazanova Ekaterina Aleksandrovna - a specialist in risk assessment methods of social risk analysis laboratory (e-mail: ryazanova@fcrisk.ru; tel.: +7(342) 237-25-47).

* This article was prepared with financial support from RHF (project №16-16-59007). 
most outstanding issue here is to create a versatile typology of risk-generating behavior for working population whose health is exposed to risks related to their professional activity.

Research goal. Our goal was to work out a risk-generating behavior typology (behavior which can generate health risks) basing on defining general behavioral regularities related to health, as well as to test it on an example of manufacturing enterprise workers.

Data and methods. To create our typology we used the data of sociological questioning conducted in the form of an interview at a working place among workers employed by an enterprise manufacturing rubber articles for industrial and consumer markets. The sample included only workers, who at their working place were constantly exposed to such hazardous chemicals as petrol, dichloromethane, dichloroethane, styrene, benzpyrene etc. Joint effect of these chemicals and behavioral factors of workers' lifestyle in future might lead to faster diseases evolvement and more apparent health disorders [4].

We conducted interviewing 63 workers (57.1\% male and $42.9 \%$ female) and basing on the results of these interviews we planned to define 3 types of workers' groups: the $1^{\text {st }}$ type with low risk-generation level, the $2^{\text {nd }}$ type with average risk-generation level and active; the $3^{\text {rd }}$ type with high risk-generation level. We based our typology on the data characterizing individual parameters of workers' behavior. As researchers we were mostly interested in determining medical behavior peculiarities, studying smoking and alcohol drinking practices, workers' physical activity, as well as following eutrophy standards.

Our research instrument was a well-structured questionnaire containing blocks of questions which enabled us to define characteristics of examined workers' groups in terms of their following basic standards and rules of healthy lifestyle. The questionnaire structure included questions aimed at analyzing:

-medical behavior, namely how workers usually visited medical specialists in case of any health problems; whether workers tended to take preventive examination on their own initiative; how they controlled their main health parameters (blood pressure, blood cholesterol, cardiac rate, waist and hips size etc);

-physical activity, namely frequency and weekly number of hours spent on doing sports; frequency of daily walks on foot; -following eutrophy standards, namely particular types of products and dishes consumed by workers at breakfast, lunch and dinner; frequency of food taking at a time less than 2 hours before sleep and "dry eating" frequency;

-smoking, namely defining the very fact of smoking, smoking frequency and experience, number of cigarettes smoked a day (over the last 3 days prior to the questioning), nicotine contents in cigarettes (marks of cigarettes);

-alcohol drinking, namely frequency of a particular alcohol drink intake over the last year (before the questioning) and average quantity of alcohol drinks taken.

When working out risk-generating behavior typology we used techniques and approaches presented in 2.1.10.0033-11 Guidelines "Assessment of risk related to lifestyle factors' effect on population health" [5].

Peculiarities of alcohol drinking and nutrition separate components were defined in two steps. Thus, when we assessed alcohol drinking we calculated daily pure alcohol intake into a body $\left(F^{A}\right)$ and values of malnutrition integral index $\left(F^{P}\right)$ [4].

To calculate average daily intake of pure alcohol $\left(F^{A}\right)$ we used the following formula:

$$
F^{A}=\frac{\sum_{i} \sum_{b} A_{i}^{b} k^{b}}{n},
$$

where $A_{i}^{b}$ is average (per sample) quantity of $b$ type alcohol drink, consumed on $i$-day $(\mathrm{y}), k^{b}$ is a coefficient of transforming $b$-type alcohol drink into "pure alcohol", $n$ is the quantity of days analyzed [4].

To calculate the index we used variables showing frequency and quantity of a particular alcohol drink taken. All the variables were represented in a form of an ordinal scale consisting of 9 gradations characterizing frequency of a concrete alcohol drink intake over a year and its average quantity consumed at a time.

As we transformed variables showing quantity of a concrete taken alcohol drink into ethanol we obtained standardized metric variables showing average quantity of pure alcohol intake in grams when a concrete alcohol drink was consumed.

$F^{A}$ index calculation was based on a product of average frequency intake for a concrete alcohol drink (over a weekly consumption) and an average quantity of alcohol intake in grams. We used zeroing values from Guide of Mental Health in 
Primary Care [15] to determine four behavioral types characterizing the examined workers.

We considered malnutrition integral index to be the sum $N_{\text {мод }}$ (parameter characterizing daily frequency of food intake) and a variable characterizing energy intake of a respondent's nutrition consumed at dinner in comparison with a daily intake $\left(A_{\text {мод }}\right)$, divided by 2 . The index was represented by an ordinal scale with 3 gradations where "1" meant normal food intake, "2" was moderate food intake and " 3 " was extremely rare food intake. We considered the formula-making parameters to be equivalent. The values varied from 1 to 3 . The critical value of $F^{P}$ was equal to $1.5[5]$.

To calculate $A_{\text {мод }}$ we used variables characterizing a respondent's typical energy intake. Variables were in the form of a dichotomic scale where respondents had unlimited choice of those positions (dishes) which they usually took for breakfast, lunch and dinner. Later on those variables were converted and average daily quantity of $\mathrm{kcal}$ was calculated for each respondent. We also calculated a share of $\mathrm{kcal}$ taken at dinner in overall daily energy intake. The values of an obtained variable which were within the range from $0 \%$ to $50 \%$ were converted into " 1 " and considered to be "norm"; values within the range from $50 \%$ to $70 \%$ were converted into " 2 " and considered moderate; values higher than $70 \%$ were converted into " 3 " and considered unacceptable. Metric values scale for $F^{P}$ index varied from 1 to 2.5 and the critical value was equal to 1.5 . [5]. $F^{P}$ index and such questions as "How often do you eat your food dry?" and "Do you eat before going to sleep?" after logical actions with expressions became overall nutrition characteristic. We also created medical behavior parameters, physical activity parameters, and smoking parameters with the use of logical actions with optional answers to questions.

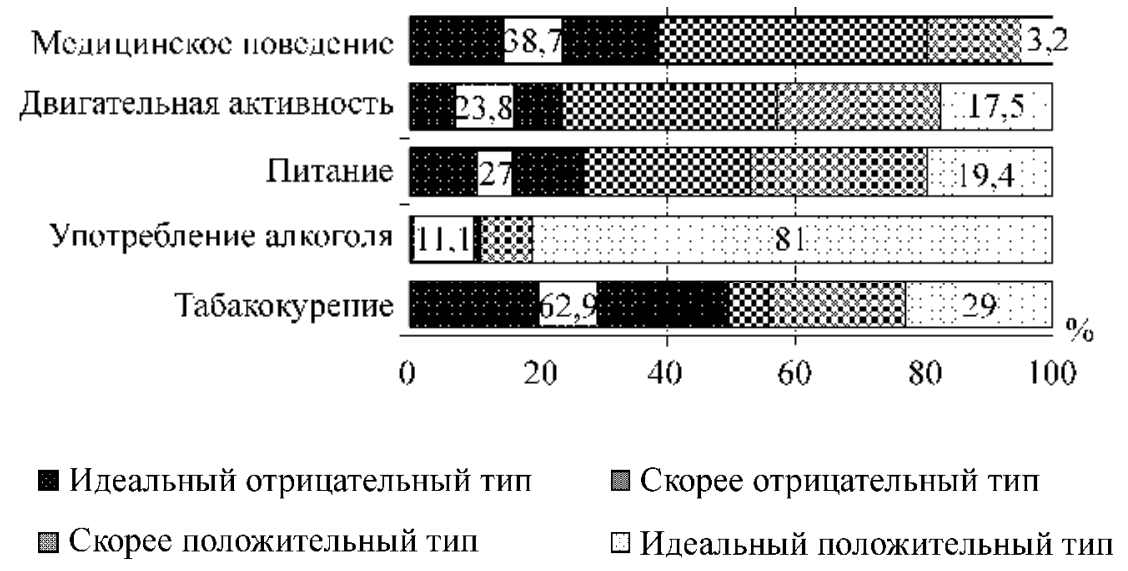

Picture 1. Distribution of workers in terms of risk-generating behavior types.

Scales names: medical behavior, physical activity, nutrition, alcohol drinking, smoking. Below the scales there are types: ideal negative, rather negative; the second line - rather positive and ideal positive.

Created characteristics of smoking, nutrition, medical behavior, physical activity and alcohol drinking were in the form of an ordinal scale with 4 gradations where "1" was "an ideal positive type" and "4" was "an ideal negative type". Gradations " 2 " and " 3 " were "a rather positive type" and "a rather negative type". Assessment of cause-and-effect relations between distinguished types of risk-generating behavior and data on workers' health status were carried out with the use of odds relations $(\mathrm{OR})$ procedure ${ }^{1}$.

\footnotetext{
${ }^{1}$ The relation was considered authentic provided that CI lower bottom was $>1$.
}

To carry out statistic evaluation of obtained data we used application package SPSS 19.0 for Windows and Ms Office Excel. As for mathematic evaluation, we used descriptive and cross-tabulation statistics.

Results and discussion. We determined that a distinctive feature of the examined workers' group was behavior characterizing ideal (polar) risk-generating peculiarities. That trend was greatly visible in terms of medical behavior and smoking (picture 1). 
As for smoking, ideal negative type was represented by workers who smoked more than 10 cigarettes a day, and ideal positive type comprised workers without any smoking experience. In terms of alcohol drinking we considered male workers drinking on average more than 35 grams of ethanol a day, ${ }^{1}$ and female workers more than 20 grams, to belong to ideal negative type. Ideal positive type was represented by workers of both sexes whose daily ethanol intake was less than 10 grams.

Ideal negative type of medical behavior was represented by workers who didn't take any preventive examinations, didn't control primary health parameters and didn't apply for medical care in case of any health problems. Workers with opposite behavioral patterns belonged to ideal positive type.

Ideal positive physical activity was characterized with regular sport training (not less than 3-5 times a week) and everyday walks on foot lasting more than 40 minutes. Absence of any sport activities and walks were characteristics of negative physical activity type.

Ideal positive type in terms of nutrition was represented by workers who ate 3 or more times a day, with "light" dinner being not more than 50\% of a daily food intake, and who didn't eat at a time less than 2 hours before going to bed and didn't eat their food dry. Workers who had opposite behavioral practices concerning nutrition represented ideal negative type.

We had one more hypothesis in our research and it was an assumption that risk-generating behavior level correlated with a worker's demographic characteristics and social status. To check the assumption we used cross-tabulation analysis and it allowed us to define that riskgenerating behavior concerning nutrition, smoking and physical activity was defined by respondents' age and sex; alcohol drinking correlated with workers' level of education.

Thus, ideal positive type in nutrition consisted of $83.3 \%$ women; and negative was characteristic for men in $70.6 \%$ cases (Cramer's V=0.47, $\mathrm{p} \leq 0.015)$. The main age group of workers belonging to ideal positive type was 36-45 (41.7\%); respondents belonging to ideal negative type were 26-35 years old (35.3\%; Cramer's V $=0.23, \mathrm{p} \leq 0.041$ ).

Women also accounted for $66.7 \%$ of ideal positive type in smoking; men belonged to ideal

${ }^{1}$ Hereinafter, the resulting averages are presented to drink alcoholic beverages in terms of pure alcohol negative type (72.3\%; Cramer's $\mathrm{V} \leq 0.214$, $\mathrm{p} \leq 0.038)$. Age of positive type workers was within 46-55 (38.9\%); as for negative type workers their age was 36-45 (30.8\%; Cramer's V $=0.246$, $\mathrm{p} \leq 0.045$ ).

Regular physical activity and walks on foot were characteristic to a greater extent for younger men (Cramer's V $=0.327, \mathrm{p} \leq 0.028$ ). Mostly elderly women were among workers who didn't do any sport and rarely walked on foot (Cramer's V $=0.238, \mathrm{p} \leq 0.037$ ).

Smoking and education level were the most significant factors affecting workers' addiction to alcohol. Most respondents belonging to "ideal positive type" had higher education (64.7\%), and those of "ideal negative type" had secondary or elementary vocational education $(57.1 \%$; Cramer's $\mathrm{V}=0.461, \mathrm{p} \leq 0.013)$. The secondary factor determining high level of alcohol addiction was the age at which workers began to smoke regularly $(\mathrm{r}=(-) 0.4, \mathrm{p} \leq 0.031)$.

We didn't detect any relations between riskgenerating behavior types and income levels though a number of research works contained some evidence of their occurrence [5]. We can assume that influence of a financial factor is leveled off in small towns where urbanization rate and production development is low as more than half of workers $(51.7 \%)$ can be considered "needy" (they have less than 10,000 rubles per family member a month), and a share of workers having incomes of more than 25,000 is very low $(5.2 \%)$.

Risk-generating behavior of the examined workers (apart from sex and age which are primary factors exerting influence on it) is determined by a number of other factors, namely social environment. For example, workers smoke because a member of theirs family is also an active smoker (Cramer's V $=0.3, \mathrm{p} \leq 0.024$ ).

We didn't detect any particular factors determining medical behavior.

Cluster analysis of aggregate features showed that the first group "low risk-generation level, passive" was made up of $30.2 \%$ of workers who didn't have any smoking experience, didn't drink alcohol, followed all eutrophy standards but didn't have much physical activity. As for risks which were characteristic for that group of workers they included, though to a lesser extent, cardiovascular diseases risk (ischemic heart disease, arterial hypertension), respiratory disorders (chronic obstructive heart disease).

As for social and demographic background, that group mostly consisted of women (48.1\%; 
Cramer's V $=0.365, \mathrm{p} \leq 0.015)$, older than 56 (44.4\%; Cramer's V $=0.224 ; \mathrm{p} \leq 0.036$ ), with higher education (53.8\%; Cramer's V $=0.274, \mathrm{p} \leq 0.05)$ and income starting from 20,000 rubles.

The second group consisted of $52.4 \%$ workers and it was "moderate risk-generation level, active". That type was characterized with more active lifestyle, daily sport activities and high frequency of walks on foot. Workers from that group didn't have any addiction to alcohol. The most significant problems for the second group workers were smoking and absence of rational nutrition habits. That type was mostly represented by young men $(58.3 \%)$, aged $36-45(58.8 \%)$, with secondary and elementary vocational education (64.9\%), with low financial status as well (income per one family member from 15,000 to 20,000 rubles a month). Such behavior type generates risks of cardiovascular diseases (aortic aneurysm, ischemic heart disease, infarction etc.), oncologic diseases (malignant neoplasms in bronchial tubes and lungs, esophagus, stomach, pancreas, etc), digestive system diseases (gastritis, stomach and duodenum ulcer etc) and others.

The $3^{\text {rd }}$ type, "high risk-generation level", was aggregated from most unacceptable behavioral patterns having obvious health-destructive trend. Workers with such type of risk-generating behavior had nicotine and alcohol addiction (21 cigarettes per day on average; average length of smoking period 23 years; average daily pure ethanol intake 60.2 grams with safe standard being 30 grams). Nutrition habits, as well as physical activity level in that group could also be called unacceptable.

That group, just like the previous one, was made up of men (25\%), aged 26-35 (31.8\%), with school education (54.5\%), with income of about $20,000-25,000$ thousand rubles per family member $(28.6 \%)$. That group accounted for $17.5 \%$ of all workers. And it was that group which could generate significant losses due to disability to work.

Cause-and-effect relations analysis showed that there were distinctive discrepancies between risk-generating behavior types and situations when workers applied for medical care because of the following nosologies: apparatus system and connection tissue diseases (Cramer's V=0.277; $\mathrm{p} \leq 0.048$ ); nervous system diseases (Cramer's $\mathrm{V}=0.267 ; \mathrm{p} \leq 0.034)$; circulatory system diseases (Cramer's V=0.378; $\mathrm{p} \leq 0.02$ ) and endocrine system diseases, nutrition and metabolism disorders (Cramer's V=0.394; $\mathrm{p} \leq 0.047$ ).

Odds relation calculation based on the data obtained in the course of workers' groups medical examination showed that pathologies risk in terms of determined diseases categories grew steadily depending on the type of their risk-generating behavior (Table 1).

Table 1 - Dependence of non-infectious diseases evolvement on workers' risk-generating behavior

\begin{tabular}{|c|c|c|c|}
\hline \multirow{2}{*}{ Disease category } & $\begin{array}{c}\text { Cluster } 2 \text { - Moderate risk-generating } \\
\text { level, active }\end{array}$ & \multicolumn{2}{|c|}{ Cluster 3 - High risk-generating level } \\
\hline & $\begin{array}{l}\text { OR in comparison with } 1 \text { cluster } \\
\text { workers }\end{array}$ & $\begin{array}{c}\text { OR in comparison with } \\
1 \text { cluster workers }\end{array}$ & $\begin{array}{l}\text { OR in comparison with } \\
2 \text { cluster workers }\end{array}$ \\
\hline $\begin{array}{l}\text { Blood and blood-making organs } \\
\text { diseases }\end{array}$ & 2.69 & 3.79 & 2.12 \\
\hline $\begin{array}{l}\text { Endocrine system diseases, nutrition and } \\
\text { metabolism disorders }\end{array}$ & 3.33 & 4.57 & 2.34 \\
\hline Nervous system disorders & $*$ & 3.00 & 2.14 \\
\hline Circulatory system diseases & 1.85 & 2.41 & 1.46 \\
\hline Apparatus system diseases & $*$ & 1.46 & $*$ \\
\hline
\end{tabular}

Note $: *-$ the connection between the indicators has not been established.

Workers who have negative risk-generating behavior types, especially combined with hazardous production factors, run greater risks of negative changes in body organs, first of all, endocrine and cardiovascular diseases, and secondly, nervous system and apparatus system disorders.

Conclusions. Prevalence of self-destructive behavioral patterns among workers may greatly strengthen negative influence of hazardous production factors.

Determining risk-generating behavior types allows to define the most vulnerable key group of workers who run higher risks of health disorders and to create a goal-oriented health management system at an industrial enterprise. At the examined industrial enterprise this risk group is made up of male workers, aged 26-35, with secondary or elementary vocational training, working at 
workshops, with monthly income from 20,000 to 25,000 rubles per family member. Their main behavioral risk factors are widely-spread smoking and irresponsible medical behavior. To a lesser extent we saw a failure to follow rational nutrition standards, alcohol deviation and low physical activity.
The data we obtained when determining riskgenerating behavior types, defining groups and risk factors, can be and should be used as a ground for working out and implementing efficient goaloriented programs of health protection and improvement for workers employed by that industrial enterprise.

\section{References}

1. Abrosimova M.Ju., Muhamedrahimova L.V. Samosohranitel'noe povedenie uchashhejsja molodezhi [Self-protective behavior of studying young people]. Bjulleten' NII soc. gigieny, jekonomiki $i$ upr. zdravoohr. im.N.A.Semashko, Moscow, 2003, no. 7, pp. 73-76. (in Russian).

2. Bunas A. A. Razlichnye aspekty obosnovanija prirody riskovannogo povedenija lichnosti [Different substantiation aspects of the nature of a person's risk behavior]. Psihologija: problemy prakticheskogo primenenija: materialy II mezhdunarodnoj nauchnoj konferencii. Chita: Izdatel'stvo Molodoj uchenyj, 2013, pp. 10-16. (in Russian).

3. Vlasova E.M., Alekseev V.B., Shljapnikov D.M. Narushenija zdorov'ja u rabochih titanomagnievogo proizvodstva [Deteriorations of health condition in furnace and smelter employees of the titanium and magnesium industry]. Gigiena i sanitarija, 2015, vol. 94, no 2, pp. 50-53. (in Russian).

4. Zaitseva N.V., Shur P.Z., Lebedeva-Nesevrya N.A. Vlijanija social'no-jekonomicheskih faktorov riska na zdorov'e rabotnikov promyshlennyh predprijatij [The regularities of socio-economic risk factors affecting on health of industrial workers]. Biomedicinskij zhurnal Medline.ru, 2010, vol. 11, pp. 538-547. Available at: http://www.medline.ru/public/pdf/11 045.pdf (24.04.2016) (in Russian).

5. MR 2.1.10.0033-11. Ocenka riska, svjazannogo s vozdejstviem faktorov obraza zhizni na zdorov'e naselenija: Metodicheskie rekomendacii [MR 2.1.10.0033-11. The assessment of lifestyle risk factors' influence on the population's health: Guidelines]. Moscow: Federal'nyj centr gigieny i jepidemiologii Rospotrebnadzora, 2011, 62 p. (in Russian).

6. Shljapnikov D.M., Shur P.Z., Atiskova N.G., Hasanova A.A., Alekseev V.B. Ocenka riska zdorov'ju naselenija, obuslovlennogo himicheskim zagrjazneniem pit'evoj vody, i svjazannyh s nim poter' [Assessment of population health risk associated with the chemical pollution of drinking water and losses connected with it]. Kompleksnoe vozdejstvie faktorov okruzhajushhej sredy i obraza zhizni na zdorov'e naselenija: diagnostika, korrekcija, profilaktika: mat. plenuma Nauchnogo soveta RF po jekologii cheloveka i gigiene okruzhajushhej sredy, Moskva, 11-12 dekabrja 2014 g. Moscow, 2014, pp. 467-469 (in Russian).

7. Rusinova N.L., Ozerova O.V., Safronov V.V. Kurenie v Rossii: social'nye razlichija i tendencii v 1990-e i 2000-e gg. [Smoking in Russia. Social differences and trends in $1990^{\text {th }}$ to $2000^{\text {th }}$ ]. Sociologicheskie issledovanija, 2013, no. 3, pp. 104-113. (in Russian).

8. Shkljaruk V.Ja. Samosohranitel'noe povedenie v molodezhnoj srede [Health behavior in teenage milieu]. Sociologicheskie Issledovanija, 2008, no. 10, pp. 139-142. (in Russian).

9. Ansari-MoghaddamA., Ansari H., Mohammadi M., Khosravi S., Sanei-Moghaddam E., Miri-Bonjar M. Predictors of High-Risk Behaviors in Municipal Workers and Staff in Zahedan, South-East of Iran. International Journal of High Risk Behaviors and Addiction, e27555. DOI: 10.5812/ijhrba.27555. Available at: http://jhrba.com/?page=article\&article_id=27555 (22.05.2016).

10. Baskin-Sommers A., Sommers I. The co-occurrence of substance use and high-risk behaviors. J. Adolesc. Health, 2006, vol. 38, no. 35, pp. 609-611.

11. Brewer N.T., Weinstein N.D., Cuite C.L., Herrington J.E. Risk perceptions and their relation to risk behavior. Ann Behav Med, 2004, vol. 27, no. 2, pp. 125-130.

12. Haghdoost A., Abazari F., Abbaszadeh A., Dortaj Rabori E. Family and the risky behaviors of high school students. Iran Red. Crescent. Med. J., 2014, vol. 16, no. 10, e15931. DOI: 10.5812/ircmj.15931.

13. Hampson S.E., Andrews Ju.A., Barckley M. Conscientiousness, perceived risk, and risk-reduction behaviors: a preliminary study. Health Psychology, 2000, vol. 19, no. 5, pp. 496-500.

14. Health and Behavior. The Interplay of Biological, Behavioral, and Societal Influences Institute of Medicine (US) Committee on Health and Behavior: Research, Practice, and Policy. Washington (DC): National Academies Press (US), 2001. DOI: 10.17226/9838

15. WHO Guide to Mental Health in Primary Care. Adapted for the UK, with permission, from Diagnostic and Management Guidelines for Mental Disorders in Primary Care: ICD-10 Chapter V Primary Care Version. London: Royal Society of Medicine Press Limited, 2000. 
Ryazanova E.A. To the problem of typology of the riskogenic behaviour (analysis on the example of an industrial enterprise of Perm region). Health Risk Analysis, 2016, no. 2, pp. 68-75. 